\title{
EMAKEELE SELTSI KEELETOIMKOND XX SAJANDI II POOLEL
}

\author{
TIIU ERELT
}

\begin{abstract}
Annotatsioon. Artikli esimene pool on ülevaade Emakeele Seltsi keeletoimkonna viljakast I tegevusperioodist aastail 1969-1972. Järgnevail aastail tegutsesid teised keelekomisjonid ning vajadus seltsi keeletoimkonna järele peaaegu puudus kuni 1990. aastateni. 1993. a toimkond taasloodi ja algas praeguseni kestev II tegevusperiood, mida artiklis käsitletakse lühidalt, viidates varem ilmunud ülevaadetele. Nende ülekordamise asemel on võetud sisulise näitena ette algustäheortograafia arutelud läbi aastate, alustades nn käändumatu omadussõna õigekirja korrigeerimisest ning lõpetades selgema reeglistiku „Algustäheortograafiast ja jutumärkidest“ valmimisega 1994. a ja selle hilisemate täiendustega. Toimkonna tegevus on alati toetunud eesti keele uurimise tulemustele ja keelekorraldusteooriale.
\end{abstract}

Võtmesõnad: Emakeele Selts, keeletoimkond, eesti keelekorraldus, keelesoovitus, keelereegel

Eelmise sajandi kahe- ja kolmekümnendail aastail oli põhiline keelenormide kokkuleppimise koht Eesti Kirjanduse Seltsi (EKS) keeletoimkond (Kask 1938). Ent parajasti kerkinud õigekeelsusküsimusi ja väljaannete keelevalikuid lahendati sageli ka Emakeele Seltsis (ES), kus tegutses paar ajutist komisjonigi. Vahel tuli klaarida ESi ja EKSi seisukohtade erinevusi. Tehti ära suur töö keeleõpetuse ja keeleteaduse ning sõjanduse oskussõnavara arendamisel, nõustati teisigi erialasid. Palju tööd oli kohanimedega (raudteejaamad, postiasutused, Setu- ja Ingerimaa, kogu Eesti sõjaväekaardid jm) ja isikunimedega (nimeraamatud).

1940. aastal katkes kaheks kümnendiks Eestile iseloomulik kollektiivse keelekorraldusorgani traditsioon. Neljakümnendail olid keeleasjad arusaadavalt päris kõrvalised ning viiekümnendail otsustati ettetulnud keeleküsimusi kahes asutuses: Keele ja Kirjanduse Instituudi sõnaraamatute sektoris ja Eesti Riiklikus Kirjastuses. Esimeses oli autoriteet Ernst 
Nurm, teises Elmar Elisto. Emakeele Seltsi panus keelekorraldusse ja -hooldesse nii kahe- ja kolmekümnendail kui ka vähemal määral nelja- ja viiekümnendail aastail väärib kindlasti uurimist ja eraldi artiklit (sh hiina ja kreeka nimede kirjutamise arutelud). Järgnevas alustan aga mõne aspekti vaatlust alates kuuekümnendaist.

Mõne konkreetse keeleasja selgitamisest eri institutsioonides ei piisanud ning 1960. a loodi eesti kirjakeele kõige üldisemate ja põhimõtteliste probleemide lahendamiseks Eesti NSV Teaduste Akadeemia juurde vabariiklik õigekeelsuskomisjon (VÕK). Selgus aga, et sellelt suurelt heterogeenselt komisjonilt lahendusi peaaegu ei tulnud, enamik uuendusettepanekuid lükati pärast arutamist tagasi.

1962. a otsustas ESi juhatus luua seltsi juurde kaks toimkonda keele- ja murdetoimkonna. Viimane küll taasluua: esimest korda asutati murdetoimkond ESi juures 1926. Keeletoimkonna ülesandeks seati tegelemine keelekultuuri ja õigekeelsusküsimustega. Algne nimetuski oli keelekultuurikomisjon. Esimeheks valiti Eduard Vääri, oli veel neli liiget. Juba 1963. a vahetati välja nii esimees kui ka pooled liikmed. Paar aastat oli esimees Arnold Kask (kuigi ta toimkonda vajalikuks ei pidanud), siis 1967. a taas Vääri. Seltsi aruandes kirjutati aga endiselt, et ,toimkond praktiliselt tegevusse ei asunud“. (Nende aastate kohta vt ka Valge 2020: 52-57.) 1968. a jättis Vääri toimkonna maha ja juhtimine läks Rein Kulli kätte (ametlikult aastakoosolekul 1969). Siit alates hakkas komisjon tegutsema 7-liikmelisena, keelekorralduslik tegevus oli täiesti tema peal kuni 1972. aastani, kui algas vabariikliku õigekeelsuskomisjoni II tegevusperiood.

ESi toimkond andis mitme keeleprobleemi kohta lahendussoovituse. Arutatud oli „laiendatud koosseisuga“, kuid sedagi ei peetud tollases ülimalt alalhoidlikus õhkkonnas piisavaks ning samad asjad arutati veel mitu korda läbi VÕKis, kus üle poolte liikmete olid samad. Tuli saada veel autoriteetsemad otsused. Näiteks adjektiivsete liitüksuste kokkukirjutamist arutati 16. X ja 23. XII 1970 ning 29. I 1971 ESi keeletoimkonnas, 14. IV ja 10. V 1972 VÕKis. Vähemalt oli sellega uuele VÕKi koosseisule 1972. aastaks materjal ette valmistatud.

Miks toimkonna töö pärast pikka vindumist 1968. a lõpus järsku sisukaks läks? Peamine põhjus oli see, et teoksil oleva uue õigekeelsussõnaraamatu tarvis tuli saada kinnitust mõnelegi ÕSi tegijatel küpsenud muutmisettepanekule. Sõnaraamatut, millest sai ÕS 1976, koostasid tol 
ajal Tiiu Erelt, Rein Kull, Valve Põlma ja Kristjan Torop, toimetajaiks said Rein Kull ja Erich Raiet. ESi keeletoimkonnas olid Kull ja Raiet, koosolekuil osales protokollijana Erelt, neist said 1972. a ka VÕKi liikmed (seejuures Raiet aseesimees, Erelt teadussekretär).

Rein Kull avaldas ESi aastaraamatus neljaosalise kokkuvõtte toimkonna tollastest otsustest ja soovitustest (Kull 1971: 251-260):

(1) stik-sufiksi liitumisest.

(2) Võõrsõnade ortograafia küsimusi.

(3) Adjektiivsete liitüksuste kokkukirjutamisest.

(4) Soovituskiri kaubanduskeele parandamiseks.

Neist kolme esimest 1969. ja 1970. a tööd tutvustati ka ajalehtedes Sirp ja Vasar ning Nõukogude Õpetaja, ajakirjas Keel ja Kirjandus. Toimkonna õigekeelsusotsustega täideti vahet VÕKi tegevuses 1965-1972 ning, nagu öeldud, läksid need 1972. a veel VÕKi.

Eriti mõjus oli omal ajal aga neljas punkt, s.o „Soovituskiri kaubanduskeele parandamiseks. Toidukaupade ja roogade nimetustest". Kuigi koostatud toidukaupade põhjal, käis see kõigi muudegi toodete kohta. Esitatud seisukohad kiideti heaks toimkonna koosolekul 21. I 1970, lõpliku kuju sai tekst aasta lõpus ning saadeti siis välja kaubandusministeeriumile, toiduainetetööstuse ministeeriumile, liha- ja piimatööstuse ministeeriumile, ETKVLile, sööklate, restoranide ja kohvikute trustile, riiklikule hindade komiteele. Neis keskasutustes ei jäänud soovituskiri sugugi tähelepanuta, vaid seda levitati oma süsteemi allasutustes ja väljaannetes. Suure keelematerjali põhjal ning asjatundjate abi kasutades olid tehtud 11 üldistavat soovitust, mis pole aktuaalsust kaotanud ka praeguseks. Vahetunud on mõjukeel: vene keele asemele on tulnud inglise keel. Kahjuks on see suur töö vajunud unustusse (ikkagi pool sajandit möödas).

Rohkesti tuletatakse meelde hoopis 1972. a sõnavõistlust, mis oli ainulaadne üritus eesti sõnavara arendamise ajaloos. See oli rahvalik sõnaloomevõistlus, mille hoidmiseks kindlamas voolusängis valis keeletoimkond õnnestunud korraldusmalli: huvilistele anti ette 20 mõistet, mis ootasid paremat väljendust. Eeskuju saadi Soomes peetud (küll palju tagasihoidlikumast ja kesise saagiga) võistlusest. Samamoodi on korraldatud ka hilisemad sõnavõistlused, mis küll otsekohe ei järgnenud, aga mida on uuel aastatuhandel olnud rohkesti (vt Maire Raadiku ülevaade raamatus „Uudissõnu uue aastatuhande algusest“ (2017: 165-189)). 
1972. a sõnavõistlus andis päris suure hulga siiani kasutusel olevaid sõnu, nagu kohuke, linnak, pardel, selve, sõ̃rik, särgik, eirama, oskuskeeles meerik. Omal ajal kasutusse tulnud taidlust ja kolklust ei lähe praegu enam tarvis, sest sõnade elukäik oleneb suuresti nendega tähistatavate mõistete tarvilikkusest. Võistlust ja selle tulemusi tutvustati laialt ajakirjanduses (Õhtuleht, Noorte Hääl, Edasi, Sirp ja Vasar) ja ESi keelepäevadel. Pikemad artiklid olid Rein Kulli „Sõnavõistlus ja võistlussõnad“ (1972) ja Tiiu Erelti „Võistlussõnade esimene eluaasta“ (1973).

Tollast üritust võib hinnata mitut moodi. Üks arvamus on olnud, et see oli tühi asendustegevus. Teine arvamus on: „Eesti keel on rikastunud mitmete sõnadega. Veelgi hinnatavam on aga olnud sõnavõistluse osa keeleelu elavdamisel ning keelearenduse põhimõtete propageerimisel“" (Erelt 1973: 461). 1970ndail teenis keeleelu elavdamine suuresti just rahvusliku eneseteadvuse hoidmise eesmärki. Ja tuligi 182 kirja, igaühes hulk ettepanekuid, kokku 3600. Osavõtjate vanus ulatus 7 aastast 89 aastani. Eriti kõrgelt hindan aga toonase ja kõigi hilisemate sõnavõistluste antud võimalust õpetada laiale huviliste ringile sõnavara arendamise allikaid ja viise. Mittefilolooge kisub teatavasti sageli üksnes tehissõnu nuputama.

Ent tagasi toimkonna tegevuse juurde 1971. aastal. Koosolekuil olid siis (nagu ka 1969 ja 1970) arutlusel ÕSi uusväljaandega seotud probleemid ning jõuti morfoloogia juurde. Mõne üksiksõna ja sõnarühma käänamist-pööramist arutati toimkonnas neljal koosolekul ning esitati siis oma seisukohad reorganiseeritud vabariiklikule õigekeelsuskomisjonile, kus kolme koosoleku arutelud andsid 1972. aastal otsused (Erelt 1975a). Nii sellest ESi aastaraamatu kirjutisest kui ka ajalehtedes Sirp ja Vasar ja Nõukogude Õpetaja ning ajakirjas Keel ja Kirjandus ilmunust võib lugeda järgmiste sõnade kohta: köömen ja kööme, järg ehk järi, päike, äike ja väike, sümptoom ehk sümptom, oktaav ehk oktav, ofset, bakšiš, 3-silbilised or-lõpulised termistor, transistor, varistor jts, võõrpäritolu 2-silbilised pika vokaali või diftongi ja lühikese üksikkonsonandiga us-sõnad, nagu gloobus, saurus, poolus, toonus, on-lõpulised sünteeskiu ja elementaarosakeste nimetused, hälbima, pürgima, laskma, haug ehk havi, 2-silbilised III-vältelised er-lõpuga sõnad (mida käänata nagu album ja mida nagu number). Ei olnud kaelamurdvad probleemid, aga igasugune väikegi muutus oli vanemale põlvkonnale vastukarva (eriti omasõnade käänamises-pööramises). Nõndasamuti oli ESis olnud ka 1920. aastail. Kergem olnuks kaamel läbi nõelasilma ajada kui mõne paralleelvormi 
lubamine saavutada. Nende otsuste tuules tulid aga VÕKi II koosseisus pärast kõne alla ka suuremad probleemid: jalg-tüüpi sõnade konsonant-ja vokaaltüvelise te- $\sim d e$-mitmuse vahekord ning $i$-mitmuse ja $i$-ülivõrde esitamine ÕSis (kas otsustada üksiksõnuti või tüübiti). Soovitused nende muuttüübiti lahendamiseks kujunesid kergemini, suuresti tänu prof Paul Alvre tugevale osalusele.

1971. a arutas ESi keeletoimkond veel terminite soe ja soojus vahekorda. Sellest oli Tallinna Polütehnilise Instituudi professori akadeemik Leo Jürgensoni algatusel ja hoogsa selgitustöö tulemusena saanud tollase tehnikakeele fookus, aga filoloogide kogu polnud probleemipuntra, täpsemalt riiu lahendamiseks õige koht. Jürgensonil kui elamute ja lautade soojapidavust uurival ehitusfüüsikul oli kahe mõiste eristamine tarvilik ning ta ei mõistnud, kuidas ülejäänud inimesed sellest aru ei saa ega hooli.

Koos geograafidega arutas toimkond eesti nimede vene keelde transkribeerimise reeglistikku. Eesti NSV Ülemnõukogu Presiidium tegi vastavalt sellele 30. XII 1971. a otsusega mõned muudatused: jätta vene kirjapildis kajastamata eesti palatalisatsioon ning muuta $l$-i ja ee transkriptsiooni. Geograafid olid muutmiseks saavutanud kokkuleppe ka NSV Liidu MN Geodeesia ja Kartograafia Peavalitsuse eriteadlastega. Ilmus brošüür „Eesti pärisnimede kirjutamine vene keeles“" (1973).

Sellega sai otsa ESi keeletoimkonna eriti aktiivne periood 1969-1972. Kogu selle aja oli tegevust esimehena vedanud Rein Kull. Liikmed olid olnud Elmar Elisto, Mati Hint, Arnold Kask, Henno Meriste, Erich Raiet ja Ellen Uuspõld, töökoosolekuist osa võtnud Heino Ahven, Tiiu Erelt, Valmen Hallap, Ernst Nurm ja Henn Saari. ESi tegevusaasta 1973 aruandes on keeletoimkonna kohta öeldud: „Seoses sellega, et vabariiklik õigekeelsuskomisjon on asunud taas toimekalt tegutsema, on ära jäänud vajadus ulatuslikeks ettevõtmisteks seltsi keeletoimkonnas. Aruandeaastal piirdus töö jooksvate küsimuste lahendamisega (keeleline nõuanne) ning J. V. Veski juubelikonverentsi ja -koosolekute ettekannete ettevalmistamisega“ (Ahven 1975: 331).

Ei ole siiski nii, et keeletoimkond pärast VÕKi töölehakkamist päris üleliigne olnuks. ESi tegevuse 1974. a aruandes on kirjas, et keeletoimkonnas „on kaalutud normimuutmisettepanekuid, esildisi mõnede sõnatähenduste fikseerimiseks, uute sõnade tarvituselevõtmist, keelte lühendeid jm. Toimkond on püüdnud ettevalmistavalt läbi töötada vabariiklikus õigekeelsuskomisjonis arutusele tulevaid probleeme. Toimkond 
on andnud jooksvat keelelist nõu nii asutustele kui ka üksikisikuile“ (Ahven 1976: 205).

Keelenõu jagamine oli muidugi suuresti seotud sama tegevusega Keele ja Kirjanduse Instituudis, kus nõu anti alates instituudi asutamisest 1947. a (nõuandepäevikut hakati pidama 1966). Mis puutub aga VÕKi ja ESi keeletoimkonna rööpsesse tegutsemisse, siis tuleb arvestada, et 13-liikmelise VÕKi koosseisust üle poole olid kas ESi keeletoimkonna liikmed või selle tööga seotud inimesed. Suuremate probleemide ja normimuutmisettepanekute kaalumine tähendas aga seda, et Rein Kulli juhitav toimkond sai vähemalt pihta hakata mõnegi asjaga, mille arutamist VÕKis Arnold Kask (kui esimees II perioodil) alustadagi ei lasknud. Toimkonna aruteludega sai näidata, et ettepanekutel on poolehoidu, need pole üksnes ühe-kahe inimese seisukohad. Nii et seda tähendab eeltsiteeritud diplomaatiline lause: „Toimkond on püüdnud ettevalmistavalt läbi töötada vabariiklikus õigekeelsuskomisjonis arutusele tulevaid probleeme." Samasugune lause kordub keeletoimkonna kohta 1975. a aruandes: „Toimkond on ettevalmistavalt läbi töötanud vabariiklikus õigekeelsuskomisjonis arutusele tulevaid küsimusi: keelte ja murrete nimetused ning nende lühendid, kokku- ja lahkukirjutamine, lane-tuletised kohanimedest jm“ (Ahven 1977: 238).

Vaatame näitena üle murdenimetuste kirjutamise. Kehtis 1954. a koostatud ja ESi juhatuses vastuvõetud keelte ja murrete nimetuste ning lühendite nimestik. Selle parandamiseks koostasin VÕKi teadussekretärina Keele ja Kirjanduse Instituudi soome-ugri keelte sektori abiga 1974. a uue Uurali keelte ja murrete loendi. Eesmärk oli palju laiem kui see parandustöö. Nimelt oli mulle teoksiloleva ÕSi õigekeelsuslisasse suure ja väikese algustähe reeglistikku kirjutades selgeks saanud, et kohanimedest nn käändumatute omadussõnade loomisega ei saa enam jätkata. Olin sellest pidanud ettekande „Suur ja väike algustäht kohanimelistes täiendites“ Emakeele Seltsi kõnekoosolekul 25. IV 1971 Tartus. Tahtmine minna tagasi suure algustähe ja häälduspärastamata kuju peale tõrjuti jäigalt ja edukalt tagasi. Kehtiva reegli rakendamise raskusi ei tahetud arutadagi. (Ülevaadet nn käändumatu omadussõna õigekirja raskustest ja nende ületamise teedest vt Päll 1985.)

Kui oli selge, et terve reegli ühe korraga muutmine pole võimalik, tuli muutma hakata samm-sammult. Kes selle reegli ajalugu tunneb, see teab, et mitme aastakümne jooksul ongi nii toimunud, kuigi keeletarvitajale olnuks palju lihtsam ja kergem üksainus selge tagasiminek aastasse 1919, 
mis ajani veel kõiki kohanimesid suure tähega kirjutati (muudatuse alguse kohta ja Lauri Kettuse osa selles vt Erelt 1985: 489-490).

Loogiline samm oli alustada oma erialast. Olgu märgitud, et näiteks arheoloogid polnud kunagi sellele keelereeglile allunud ega kultuurinimetustes kohanimesid moonutanud (La Tène'i kultuur, Hallstatti kultuur, mitte lateeni kultuur, halštati kultuur). Keeleteadlastel kehtis aga separaatreegel, mille järgi murdenimetusi pandi kirja väikese tähega, murrakunimetusi suurega. Oli tarvis sellest loobuda ning kirjutada kohanimi murdenimetuses suure algustähega ja häälduspärastamata kujul (nii nagu murrakunimetusteski), nt ungari keele Székely murre (mitte seekäi), mittekohanimelised nimetused jäid väikese tähega, nt vadja keele idamurre.

Muutmiseks piisanuks ESi juhatusest (nagu 1954. a), kuid asja arutati 1974-75 pikalt ,ettevalmistavalt“ ESi keeletoimkonnas ja seejärel vabariiklikus õigekeelsuskomisjonis ning lõpuks võeti uus nimestik vastu ESi juhatuse ja VÕKi ühiskoosolekul 12. III 1975. Said sätitud ka keelte ja murrete lühendid, aga nende moodustuse üldpõhimõte jäi samaks (Erelt 1975b, 1977).

Alates 1976. aastast või õigupoolest juba 1975. aastast kandus keelekorraldusliku tegevuse fookus nimekorraldusele ja ESi toimkond enam ei kogunenud ega tegutsenud. Vabariiklikul õigekeelsuskomisjonil oli 1975-78 käsil suur töö - tollaste liiduvabariikide nimede praktilise transkriptsiooni juhiste loomine, s.o üleminek otsetranskribeerimisele ilma vene keele vahenduseta. Eeltööd tuli teha nende keelte asjatundjatega, mitte samade keeleteadlastega kahes komisjonis sama asja topelt arutada. (Et kirjastamisel seisab ees Kolgata tee ja „Nimekirjutusraamat“ ilmub alles 1993. a, ma alustades õnneks ette ei kujutanud.)

Järgnevate aastate keeleelu kulges niimoodi, et vajadust ESi keeletoimkonna järele polnud. 1978. aastaks olid küpsenud kaks suurt vastuolu: tegeliku keeletarvituse ja konservatiivse VÕKi ning keelekorralduse ja keeleõpetuse vahel. Edasimineku teid otsides ei saanud üksnes VÕKi või ESi keeletoimkonna peale loota. Nii teaduse (akadeemiksekretär Juhan Kahk) kui ka kooli (haridusminister Ferdinand Eisen) kõrgeimal tasemel otsustati 1979. a sügisel kokku kutsuda ühisnõupidamine. Selle ettevalmistamiseks pandi tööle 15-liikmeline keelekorralduse ja keeleõpetuse komisjon Huno Rätsepa juhtimisel. Ainult ühe aasta, kuid tulemusrikkalt tegutsenud komisjon korraldas sisuka nõupidamise ning andis uued sihid nii emakeeleõpetusele (kirjutada uued õpikud uue ainekava järgi 
õpetamiseks) kui ka keelekorraldusele (Erelt 2001). Kavandati VÕKi uue perioodi töökava ja pakuti osale probleemidele lahendused. Kahki taganttõukamisel VÕK reorganiseeriti ja III koosseis sai juba 1979. a tööd alustada. Komisjoni esimene abiesimees, s.o tegelik esimees oli Huno Rätsep (formaalselt Arnold Kask).

Aastail 1979-83 tegi VÕK kümme kaalukat otsust. Tollase töö põhimõtteid ja otsuseid eesti kirjakeele õigekirja, vormiõpetuse ja sõnavara alalt käsitleb „Kirjakeele teataja 1979-1983. Õigekeelsuskomisjoni otsused"، (1985).

Pingelises töös said läbi arutatud nii keelekorralduse ja -õpetuse komisjonilt 1979. a saadud ettepanekud kui ka uued esildised VÕKi liikmetelt. Kõige pakilisemate probleemide kohta olid sellega keeleteadlaste põhiseisukohad ja autoriteetse komisjoni otsused olemas. Tegutses suur, aga siiski üllatavalt teovõimas keeleteadlaste kogu (17 liiget).

Seejärel tegevus vaibus, ainult 1987. a suvel arutas VÕK veel EELK Konsistooriumi soovil piiblis olevate isiku- ja kohanimede kirjutamist. Sellega lõppes sisuline tegevus. 17. XII 1993 kogunes komisjon ühe korra, kuid sel koosolekul arutati iseennast: mida endaga peale hakata. Otsustati paberil edasi olla - ehk läheb millekski tarvis ja uuesti asutada oleks raskem. Komisjoni III koosseis oli tööle pandud ENSV Teaduste Akadeemia presiidiumi otsusega, nii saanuks ka lõpetada.

Vaadates aastaarvu 1993 teame, kui suured muutused olid Eesti ühiskonnas vahepeal toimunud. Keel ja keeleelu ei jäänud sellest puutumata. Suurele keele demokratiseerumise lainele ja selle haripunktile 1979. a järgnes 1990ndate alguses uus, veel suurem demokratiseerumise laine. Ilmnes aina rohkem nii pika aja jooksul kujunenud kui ka uusi muutusi. Vajadus tegutseva keelekomisjoni järele oli ilmselge ning juba enne VÕKi viimset koosolekut oli Tartus Veski päeval 27. VI 1993 otsustatud taasluua Emakeele Seltsi keeletoimkond. Tolle XXVI Veski päeva teema oli „Eesti keelehoole“.

Enne kui asuda käsitlema uue keeletoimkonna lugu, tuleb öelda natuke taustaks kogu seltsi kohta. Kaheksa- ja üheksakümnendate vahetusel oli Emakeele Selts kriisis. 1988. a aprillis oli surnud kauaaegne teadussekretär Heino Ahven ja novembris astus sellesse ametisse Mart Meri. Temal ja ta mõttekaaslastel oli kihk kõike muuta, mis on üsna seaduspärane: suured 
ühiskondlikud muutused tekitavadki inimestes uuendusmeelsust ja tegutsemisindu. Andes aru seltsi tegevusest 1989. aastal rääkis Meri, et selts on tegutsenud juba 70 aastat, teda kammitsevad vanad väärtused ja see „võib endas peita rutiinsust". Sellest ülesaamiseks sõnastas ta varasemast erinevalt uued sihid: ,... tegevuse eesmärgiks on teadusliku informatsiooni kogumine ja talletamine ning selle informatsiooni levitamine, käigushoidmine. Lihtsamalt öeldes - Eesti filoloogide seltskondliku läbikäimise korraldamine. See tegevus sünnitab uut informatsiooni, n.ö lisaväärtust"“ (Meri 1998a: 191). Sama mõtet kordas Meri ka 1990. a aruandekõnes (Meri 1998b: 203). Seega olid sihid sõnastatud uue, infoajastu fraasidega. Juhatuse esimees Huno Rätsep taandus mitte ainult juhatuse, vaid ka seltsi tegevusest täielikult. Kardinaalne uuendus ja uutele väärtustele üleminek jäi aga ainult sõnadeks ning tegudeni ei jõutud, nendeks polnud seltsil oskust ega hakkamist. Majandusolud olid ka rasked ning ühiskondlik aktiivsus suunatud mujale kui keelele. Juba 1990. a aruandes väljendas Meri oma suurt pettumust seltsis ja tema liikmetes; ei tahetud, osatud, viitsitud uusi väärtusi teadvustada (samas, lk 203).

Ometi oli selts tollal ühiskonnale väga tarvilik, sest käsil oli uue keelepoliitika loomine. 1988. a asus ES tegutsema selle nimel, et sätestada eesti keel põhiseaduse tasemel riigikeeleks, ning 1989. a kirjutati uude põhikirja seltsi eesmärgina sisse ka „kaasa aidata eesti keele takistamatule kasutamisele riigikeelena". 1994. a töötas ESi ajutine toimkond läbi keeleseaduse eelnõu. Juhatusel ja Mart Merel tuli korraldada neid keelepoliitilisi töid (Meri 1998c: 250).

Ent tagasi keeletoimkonna juurde, mille taassünni kirjeldamist eespool alustasin ja mis seltsi üldise elu taustal on seda hinnatavam. Vajadusest sellise toimkonna järele uuel keelepoliitilisel taustal oli räägitud mitmel aastakoosolekul ning lõpuks oli loomisotsus küps. 27. VI 1993 seltsi üldkoosolekul Veski päeval valitud keeletoimkonna vanem Jaak Peebo moodustas 8-liikmelise toimkonna, kaasates neli liiget Tallinnast ja Peebot ennast arvestades neli liiget Tartust. 17. XII 1993 seltsi juhatus selle koosseisu ka kinnitas. Tasub tähele panna, et samal päeval oli veel korraks koos olnud ka vabariiklik õigekeelsuskomisjon, kes endale enam tegevust ei kavandanud (nagu eespool kirjeldatud). Eestis ei jätku inimesi mitme keelekomisjoni aktiivseks tööks. Nüüd oli taas Emakeele Seltsi keeletoimkonna kord. (Ülevaade XX sajandil tegutsenud keelekomisjonidest leidub raamatus „Eesti keelekorraldus“, vt Erelt 2002: 224-250.) 
Seltsi üldkoosolek ja toimkonna tartlastest liikmed kujutasid eesseisvat tegevust ning ülesandeid ette kui vajaduse korral kaasarääkimist keeleküsimustes (nt otsustada vaidlus, kas magistrant või magistrand). Üheksakümnendate aastate algul oli näha, et kirjakeel ei püsi enam varasemates rangetes raamides. Küllap kujutleti toimkonda keele valvaja, kaitsja ja hoidjana. Eesti Keele Instituudi keelekorraldajaile jäi sellest väheks (toimkonnas olid Tiiu Erelt, Peeter Päll ja Maire Raadik), sest teoksil oli keelekorraldussõnaraamat (millest sai „Eesti keele sõnaraamat ÕS 1999“) ja raamat „Eesti ortograafia“ (Erelt 1995). Nad soovisid, et toimkond vaataks läbi kirjakeele norme ja terveid reeglistikke ning annaks soovitused või, nagu varem öeldi, võtaks vastu otsused. (Eks seda otsuse-sõna võib tegelikult kohata hiljemgi, ka praegu on tegevuse tulemused veebis pealkirjaga ,Emakeele Seltsi keeletoimkonna otsused“‘.)

Eelkirjeldatud olukord tähendas, et 1993. a tuli ESi keeletoimkonnal sisuliselt teist korda hakata täitma vabariikliku õigekeelsuskomisjoni tegevuse vaibumise järel keelekorraldusse jäänud lünka. Nii oli olnud ka kuuekümnendail aastail. 1997. a võttis toimkond VÕKi ülesanded üle ametlikult: selle kohta on komisjoni abiesimeeste Rein Kulli ja Henn Saari kiri Eesti Teaduste Akadeemia juhatusele ja akadeemia juhatuse otsus. 1993. a de facto lõpetanud komisjon tuli lõpetada ka de iure. Selleks ajaks oli selge, et ESi keeletoimkond töötab ning VÕKi pole enam tarvis igaks juhuks paberil hoida. Oli ebamugav esitada aastaaruandeid, et midagi ei tehta.

Seoses keeletoimkonna töölerakendamisega arutati ESi juhatuses 1993. a ka seltsi keelebüroo asutamist, mis annaks nõu, korrastaks tarbetekste ja asutustesisest keeletarvitust jne. Büroo peeti tarvilikuks luua Tartus ja hõlmata Lõuna-Eesti. Samas nenditi, et selle asutamine ja tööle hakkamine eeldaks korralikku ettevalmistust ning algkapitali olemasolu. Osaliselt kommertsalustel tegutsev büroo võiks aga edaspidi ehk seltsi majanduslikku olukordagi parandada. Tookordne mõte teostus teisenedes ja mitme asutuse koostöös palju hiljem, 2007. a, kui Tartusse asutati keelehooldekeskus.

1993. a lõpus ESi juhatuses kinnitatud uus keeletoimkond andis juba 1994. a mitu olulist soovitust. Toimkonna vanem oli kuni 1996. a kevadeni Jaak Peebo, 1996-2000 Tiiu Erelt. Seda perioodi käsitleb „Kirjakeele teataja II 1993-2000. Emakeele Seltsi keeletoimkonna soovitused“ (2000), mis on sisult ja vormilt samasugune keelekorralduse väljaanne kui 1985. a 
ilmunud esimene „Kirjakeele teataja“. ESi juhatuses ja keeletoimkonnas oli küll 1993-1994 arutatud ka keelehooldebülletääni väljaandmist, kuid selleks ei saadud raha ega polnud ka vabu tegijaid (Valge 2020: 79-80).

Raamat „Kirjakeele teataja II“" algab Tiiu Erelti kirjutisega toimkonna tegevusest 1993-2000 ja selle aluseks olevatest põhimõtetest (lk 5-13). Järgnevad keelesoovitused koos iga esildise teinud autori selgitustega. Viimastes on kirjas, miks üldse mingi probleemi arutelu algatati ja reegli või isegi reeglistiku muutmise eelnõu koostati. Tegu võis olla mingi valdkonnaga, kus on praktilises tarvituses olnud raskusi, aga tervik pole juba kaua tähelepanu all olnud (nt rahvaste ja keelte nimetuste õigekiri). On kirjeldatud ka eelnõu arutamise kulgu ning nimetatud inimesi, keda on toimkonna liikmetele lisaks kaasatud (nt väliskohanimede õigekirja puhul Tartu Ülikooli ja Eesti Entsüklopeediakirjastuse geograafid). Mõni soovitus on vajanud veel kommentaari või hilisemaid täpsustusi. Alati on märgitud ka see, kus soovitus on varem avaldatud (Keeles ja Kirjanduses, Õiguskeeles või Riigi Teataja Lisas). Peale täiskujul avaldamise tutvustati soovitusi olenevalt adressaadist ka ajalehtedes Õpetajate Leht, Sirp jm, Eesti Raadio saates „Keelekõrv“, ESi keelepäevadel, õpetajaile ja toimetajaile peetud loengutes ja ettekannetes.

Üks olulisemaid ja laiema haardega probleemiringe, mida 1994. aastal, varsti pärast ESi keeletoimkonna taasloomist arutati, oli jutumärkide ja suurtähe kasutamine nimede markeerimisel. Tiiu Ereltit sundis seda arutamist algatama ja koostöös Peeter Pälliga eelnõu koostama kaks asjaolu: ,1) emakeeleõpetajad, toimetajad ja teised eesti keele eest hoolt kandvad inimesed on aastaid rääkinud vajadusest otsida uusi, kergemaid lahendusi jutumärkide ja algustäheortograafias; 2) tegelik nimekasutus on koos ühiskonnaelu muutumisega niivõrd teiseks saanud, et 1976. aasta ÕSi reeglistikust ei leia uue aja nimede kirjutamiseks enam tuge" (Erelti selgitus, lk 14; vt ka Pälli lisakommentaarid, lk 20-23). Muudatuse mõte, mille järgi reeglistik ümber kirjutati, oli reguleerida mallide kasutust: rakendada kõige rohkem kõige üldisemat eesti nimemalli SSS + väiketäheline liigisõna ees või järel (õpetaja Peeter Pirn, Hea Lootuse neem, Valge Roosi orden), „SSS“jääks käibest kõrvale või vähemalt tagaplaanile (poleks tarvis jutumärke, nt ajakiri Eesti Loodus, Kirju Kuke kohvik, valimisliit Selg Sirgeks), „Svv“ jääks ainult pealkirjamalliks (romaan ,, Tõde ja õigus “, saade „,Rahvusülikooli sajand"), Svv järele puuduks vajadus. Uus reeglistik „Algustäheortograafiast ja jutumärkidest“(lk 15-19) tekitas 
muidugi mitmesugust vastukaja nagu uuendused ikka, kuid on üldjoontes püsinud.

Hiljem on ESi keeletoimkond sügavamalt arutanud ja andnud soovitused veel järgmiste sama reeglistiku osade kohta:

1) kaupade nimetamine (Maire Raadiku eelnõu, neli arutamist 1997-1998);

2) ajaloosündmuste algustäheortograafia (Urve Pirso jt 2012);

3) kujundlike (ümberütlevate) nimetuste algustäht (Peeter Päll 2018);

4) sordinimede kirjutamine (2005, ei aktsepteeritud Eesti aiandusliidu puuviljakomisjoni soovi kirjutada sordinimedes kõik sõnad suure algustähega);

5) nimedes esinevate abisõnade kirjutamine (Peeter Päll 2006; otsustati väikese tähega alustada ainult sidesõnu);

6) stratigraafiaterminite keeleline vorm ja algustäht (Peeter Päll 2011).

Sellest ei ole aga muutunud üldpõhimõtted, pigem on nende rakendamisega mindud edasi, mitte tagasi. Näitena tuleb tuua kohanimelise täiendi suurtäheline kirjutamine. Siinses kirjutises oli eespool juttu sellest, kuidas ei õnnestunud ühe korraga pidurdada nn käändumatuid omadussõnu, aga kuidas 1974. a siiski läks korda sellega vähemalt algust teha - hakata suure algustähega kirjutama kohanime murrete nimetamisel. Teise suure sammu tegi ESi keeletoimkond oma 1998. a soovitusega „Kaupade nimetamine“ (Kirjakeele teataja II: 115-121). Maire Raadiku poolt toidukaupade õigekirja põhjal alustatu laienes arutelu tulemusena avaramaks soovituseks. ESi keeletoimkond pidas võimalikuks kirjutada kohanimi suure algustähega 1) mis tahes toodete, 2) nähtuste, viiside, meetodite jm ning 3) haiguste, ravimite, keemiliste ühendite, värvuste jm puhul (nt Camemberti juust, Türgi diivan, Hiina köök, Rootsi laud, Siberi katk, Berliini roheline). Algustähel ei tulnud nimetamisel enam kanda rasket koormat eristada liiki (väike täht) ja päritolu (suur täht). Väiketähelised nimetused tulnuks pealegi häälduspärastada (nt kamambeeri juust). Kõnealune soovitus kaupade nimetamiseks andis muidki kasulikke juhatusi, olles sellega ilus jätk ESi keeletoimkonna „Soovituskirjale kaubanduskeele parandamiseks“ (1970), mida on käsitletud siinse kirjutise algul. Kas soovitus laieneb ka taime- ja loomanimetustele, jäi vastavate alade eriteadlaste otsustada. Igatahes ei oleks kohanime reeglipärane suure algustähega kirjutamine nendes mingi eksimus. 
Kuigi kirjeldatud avara soovitusega oli väikese algustähe kasutamine ahenenud üksnes keele või rahvusega seotud ühendite peale, on veel ka hiljem kaks korda tekkinud praktilisi küsimusi. 2006. a palus Peeter Päll toimkonnal kaaluda, kuidas saaks õigekirja poolest ühtlustada sageli kõrvuti kasutatavad Rooma numbrid (kohanimi Rooma) ja araabia numbrid (araablastelt pärit). See on kõne all olnud hiljemgi, kuid praeguseni pole midagi muudetud. 2011. a oli toimkond nõus Maire Raadiku ja teiste ÕSi koostajate ettepanekuga kasutada ÕSi tähendusseletustes senisest rohkem kohanimede suurt algustähte, nt Egiptuse päikesejumal, Kreeka mütoloogia, Vana-Kreeka keelpill. Need oleksid kooskõlas võetud suunaga (Raadik 2019: 62). Nii et tasapisi on jäänud ainult rahvuskuuluvuse näitamine, nt eesti keel, eesti luule, eesti jonn.

Tahtmata siinjuures korrata raamatu „Kirjakeele teataja II“ teksti (soovitused 1993-2000), kirjeldasin üksnes ühe suure probleemipuntra lahtiharutamist läbi aastakümnete. Kahtlemata oli aga väga kasulik soovituste andmine paljude muudegi keeleteemade kohta, nagu numbrite kirjutamine (esildis Tiiu Ereltilt), põhiarvsõnade käänamine (Erelt), Eesti kohanimede õigekiri (Peeter Päll), maailma maade nimed ja nende elanike nimetused (Päll), rahvaste ja keelte nimetuste õigekiri (Päll). Selliseid soovitusi on „Kirjakeele teatajas II“ kuusteist.

Peale selle oli neil aastail arutusel veel probleemiringe, kus selgitati välja ühised seisukohad, kuid üldsuse tarvis ei peetud soovituse teksti tarvilikuks avaldada. Siia hulka kuuluvad nt ÕS 1999 toimetaja nõuküsimised tugevaastmeliste seisundivormide ja tuletiste välte nõrgenemise kohta. Üsna palju saabus toimkonnale ka kirju ning vahel küllaltki raskeid. Toimkonna kõigi liikmete seisukohtade ärakuulamise järel sai neilegi vastata, nt õigustõlkekeskuse kiri Euroopa Liidu institutsioonide nimetuste kirjutamise kohta. (ESi keeletoimkonna tegevusest pärast aastat 2000 saab lugeda veebilehelt http://www.emakeeleselts.ee/keeletoimkond. htm; vt ka Päll 2010; Kerge 2012b; Raadik 2019.)

Ajakirjades Keel ja Kirjandus, Oma Keel, Õiguskeel ja ajalehtedes on ilmunud rohkesti kirjutisi üksikute otsuste (soovituste) ning seisukohavõttude kohta. Vahel on olnud poleemikat - mõne otsuse ümber liiga palju (ajaloosündmuste nimetuste õigekiri 2012), mõne ümber liiga vähe ning vahel polegi olnud (ühend- ja väljendverbituletiste kokku- ja lahkukirjutamine 2012). Teisena nimetatud otsuse küsitavused jäid ilmselt esimesena nimetatu suure kära varju. 
Maire Raadik on keeletoimkonna tegevuse kohta aastail 1993-2018 kirjutanud, et tehtava töö ,,võib jagada laias laastus kolmeks: otsuste (soovituste) sõnastamine, protokollilised seisukohavõtud ning keelekorraldusallikate retsenseerimine ja heakskiitmine“". Ta on loendanud, et 25 aasta jooksul on toimkond teinud kokku ligi 30 otsust ja üle 40 protokollilise seisukohavõtu (Raadik 2019: 55). Samas kirjutises on kokkuvõte olulisematest tulemustest keelevaldkondade kaupa: ortograafias, morfoloogias, semantikas ja nimekirjutuses (lk 66). Toimkond on kõik need aastad ilma pikemate katkestusteta tegutsenud.

Pärast 2000. aastat on toimkonda juhtinud Reet Kasik, Tiit-Rein Viitso, Peeter Päll, Krista Kerge, Külli Habicht, Maire Raadik ja alates 2020. a sügisest Urve Pirso. Toimkonna juurde on 2018. a asutatud välisnimede töörühm. See on loodud Peeter Pälli algatusel päevakajaliste kohanimeküsimuste operatiivseks arutamiseks. Peale toimkonna liikmete kuulub rühma nimeuurijaid, geograafe, ajakirjanikke, keeletoimetajaid ja riigiametnikke. Arutelud käivad e-posti teel ja juba osaliste loetelust nähtub, kuidas kokkulepitu peaks kohe käiku minema.

Eestis on tugev kollektiivse keelekorraldusorgani traditsioon. Iseloomulik on, et see on asjatundjate kogu, mitte riigiasutus. Taustajõuks on seejuures läbi aegade olnud selline ühistegevuse vorm nagu selts: Eesti Kirjameeste Selts, Eestimaa Rahvahariduse Selts, Eesti Kirjanduse Selts, Emakeele Selts. Pisut teist moodi staatusega oli vabariiklik õigekeelsuskomisjon, mis töötas Eesti NSV Teaduste Akadeemia juures, aga selle I koosseisu pani 1960. a erandlikult tööle riigivõim: komisjon loodi Eesti NSV Ministrite Nõukogu määrusega. II ja III koosseis kinnitati bürokraatia vähendamiseks juba ainult teaduste akadeemia tasandil. Siinses artiklis olen kirjeldanud üksnes keeletoimkonna tööd ESi juures. Selleks et toimkonnal oleks Eesti ühiskonnas autoriteeti, peab ES ise olema autoriteetne akadeemiline selts. Seda ta on suutnud olla juba terve sajandi. Praegu annab ESi keeletoimkonnale eesti kirjakeele normi tagamise õigused Vabariigi Valitsuse 9. juuni 2011. a määrusega nr 71 kinnitatud „Eesti kirjakeele normi rakendamise kord“" (esimene kinnitati aastal 1995, teine 2006).

Oma kodukorra kohaselt arutab ja otsustab Emakeele Seltsi keeletoimkond, üldisi keeleküsimusi, mis talle on kirjalikult esitanud asutused või isikud või mis toimkond on ise algatanud“". Senises töös on formuleeringu ,üldisi““ alla mahtunud peale põhimõtteliste keeleprobleemide ka „avalikku huvi“ tekitanud üksikküsimusi. Kogu II tegevusperioodi 
jooksul on silmas peetud, et peale keelekorraldajate oleks toimkonnas ka õppejõude, keeleuurijaid, keeletoimetajaid, vajadust mööda kaasatakse muudegi erialade asjatundjaid.

Vastates küsimusele Emakeele Seltsi keeletoimkonna osatähtsusest Eesti keeleelus, olen 20 aastat tagasi kirjutanud, et toimkond ei ole kumbki äärmus - ei vigade vabakslaskja ega muutuva keele paigalhoidja. „Toimkond kui mitme asutuse keeleteadlaste ühiskogu püüab olla keele tasakaalustaja, s.o nii püsiväärtustest kinnihoidja kui ka uute väljendusvajaduste ja -võimaluste arvestaja ning arendaja, keele suundumuste arvestaja, ühiskonna keeleprobleemide lahendamisele kaasaaitaja“ (Kirjakeele teataja II: 13). Paistab, et sellega on nõus olnud ka toimkonna hilisematest vanematest vähemalt Peeter Päll (2006-2010), Krista Kerge (2010-2014) ja Maire Raadik (2016-2020) (vt nt Kerge 2012a; Päll 2019; Raadik 2019).

Olen siinse kirjutise esimeses pooles pikemalt vaadelnud ESi keeletoimkonna I tegevusperioodi aastail 1969-1972. See oli lühike, aga sisukas aeg, ning kompaktne ülevaade tehtust on seni puudunud. Päris tegevuseta ei oldud ka aastail 1973-1975: valmistati VÕKile ette normimuutusettepanekuid, vastati keelenõuannet vajajaile. 1993. a alanud ja praegugi kestev II tegevusperiood on vajalikul määral üle vaadatud raamatus „Kirjakeele teataja II“ ja Maire Raadiku artiklis „Emakeele Seltsi keeletoimkonna veerandsajand“", mistõttu uus läbikirjutamine või ka otsuste-seisukohavõttude kronoloogia esitamine polnud otstarbekas. Selle asemel olen kätte juhatanud allikad, vaadelnud toimkonna taasloomise käiku ning võtnud sisulise näitena ette algustäheortograafia arutelud läbi aastate. Reeglistiku liikumist selguse ja lihtsuse poole oleks kõrvalseisjal muidu raske tabada. Ülejäänud otsuste ja seisukohavõttude läbiuurimisega saab hakkama iga huviline. Nimesoovituste puhul on abiks Peeter Pälli kirjutised, nt „Miks maanimed muutuvad" (Päll 2018). Uuel sajandil said toimkonnalt abi 2006., 2013. ja 2018. a ÕSi tegijad.

XX sajandi II poolele tagasi vaadates paistab silma korrapära, et ÕSi ilmumine tõi alati kaasa keelelise mõttevahetuse elavnemise ühiskonnas (1953, 1960, 1976, 1999). 1976. ja 1999. aasta ÕSi ilmumise eelsel kümnendil tegutsesid aga hoogsalt ÕSi tegijate taotlusi toetavad keelekomisjonid, sh ESi keeletoimkond. 
Praegusele ajale, XXI sajandi kolmanda kümnendi algusele on iseloomulik keelekorpuste kasutamine. Korpused annavad uurijale rohke ainese lausa kandikul kätte. Palju kergemini saavad keelekasutust jälgida ka praegused keelekorraldajad. Korpustest saadavad kasutusarvud on tulusad siis, kui ühtlasi pannakse tähele, mis tekstiliikidest ja allikatest need arvud moodustuvad, ning juureldakse, miks see nii on. Keele varieerumine ja muutumine on keelekorraldajate tähelepanu all olnud vähemalt viimasel poolsajandil. Missugused olid seisukohad siinses kirjutises käsitletud ajal, selle olen lühidalt esitanud raamatu „Eesti keelekorraldus“ peatükis „Keele muutumine“ (Erelt 2002a: 24-34). Mõistmisele peaks kaasa aitama ka artiklid „ÕS-i toimetaja selgitab“ (Erelt 2003) ning „Keelekorralduse mõttest ja algusest" (Erelt 2002b).

Keelekorraldajale on keelekasutuse andmed siiski vaid üks vajalikke kriteeriume kõige muu kõrval, et mõnda keelenähtust hinnata ja soovitus anda. Talle ei ole „kasutuspõhisus“ ainus kriteerium. Alati on püütud arvestada, missugune muutus on keele selgusele ja väljendusrikkusele kasulik, mis neutraalne ja mis kahjulik (vt nt Saari 2004 [1995]: 740). Laial põhjal on keelenormides tehtud sadu muutusi, mis üldjuhul pole kedagi häirinud. Veel enam: neid pole tähelegi pandud, sest arvesse on võetud ka kasutuse muutumine. Kasutuse ainukriteerium tooks aga tagasi nelja aastakümne taguse moevoolu, et keel olevat täielikult isereguleeriv süsteem. Veel varasemast ajast meenuvad 1940. ja 1950. aastad: tollane „rahvakeelsus“ oli samasugune võlusõna kui nüüd „kasutuspõhisus“. Praeguses päris täbaras keelepoliitilises olukorras oleks keelearendusest (sh professionaalide nõuannetest) loobumine karuteene meie rahvuskultuurile.

\section{Kirjandus}

Ahven, Heino 1975. Emakeele Seltsi 54. tegevusaasta (1973). - Emakeele Seltsi aastaraamat 19-20 (1973-1974). Tallinn: Eesti Raamat, 325-334.

Ahven, Heino 1976. Emakeele Seltsi 55. tegevusaasta (1974). - Emakeele Seltsi aastaraamat 21 (1975). Tallinn: Eesti Raamat, 199-209.

Ahven, Heino 1977. Emakeele Seltsi 56. tegevusaasta (1975). - Emakeele Seltsi aastaraamat 22 (1976). Tallinn: Eesti Raamat, 229-241.

Eesti pärisnimede kirjutamine vene keeles. Tallinn: Valgus, 1973.

Erelt, Tiiu 1973. Võistlussõnade esimene eluaasta. - Keel ja Kirjandus 8, 457-461. 
Erelt, Tiiu 1975a. Vabariiklik õigekeelsuskomisjon 1972. aastal. - Emakeele Seltsi aastaraamat 19-20 (1973-1974). Tallinn: Eesti Raamat, 338-344. Erelt, Tiiu 1975b. Murdenimetuste kirjutamine. - Keel ja Kirjandus 7, 429-431. Erelt, Tiiu 1977. Vabariiklikus õigekeelsuskomisjonis. 1. Murdenimetuste kirjutamine. - Emakeele Seltsi aastaraamat 22 (1976). Tallinn: Eesti Raamat, 243-246.

Erelt, Tiiu 1985. Lauri Kettunen ja eesti keelekorraldus. - Keel ja Kirjandus 8, 483- 492.

Erelt, Tiiu 1995. Eesti ortograafia. Tallinn: Eesti Keele Sihtasutus. [5. trükk 2016.] Erelt, Tiiu 2001. Keelekorralduse ja -õpetuse komisjon 1979. - Emakeele Seltsi aastaraamat 46 (2000). Peatoim. Mati Erelt. Tartu, 88-115.

Erelt, Tiiu 2002a. Eesti keelekorraldus. Tallinn: Eesti Keele Sihtasutus.

Erelt, Tiiu 2002b. Keelekorralduse mõttest ja algusest. - Keel ja Kirjandus 8, $589-590$.

Erelt, Tiiu 2003. ÕS-i toimetaja selgitab. - Keel ja Kirjandus 6, 448-460.

Kask, Arnold 1938. Tänapäeva kirjakeele kujunemisteedelt. Mõningaid jooni EKS-i keelekorralduslikust tegevusest. - Eesti Kirjandus 5, 241-256. [Taastrükk Erelt 2002, 361-376.]

Kerge, Krista 2012a. Keelekorraldus: kas ka täna? - Sõnaga mõeldud mõte. Pühendusteos Tiiu Ereltile. Koost. ja toim. Maire Raadik, Tiina Leemets. (=Eesti Keele Instituudi toimetised 14.) Tallinn: Eesti Keele Sihtasutus, $67-75$.

Kerge, Krista 2012b. Uusimaid soovitusi ESi keeletoimkonnalt. - Oma Keel 2, 77-83.

Kirjakeele teataja 1979-1983. Õigekeelsuskomisjoni otsused. Koost. Tiiu Erelt, Henn Saari. Tallinn: Valgus, 1985.

Kirjakeele teataja II 1993-2000. Emakeele Seltsi keeletoimkonna soovitused. Koost. ja toim. Tiiu Erelt, Maire Raadik. Emakeele Selts, 2000.

Kull, Rein 1971. Emakeele Seltsi keeletoimkonna otsuseid ja soovitusi. - Emakeele Seltsi aastaraamat 17 (1971). Tallinn: Eesti Raamat, 251-260.

Kull, Rein 1972. Sõnavõistlus ja võistlussõnad. - Keel ja Kirjandus 9, 524-530.

Meri, Mart 1998a. Emakeele Seltsi 70. tegevusaasta (1989). - Emakeele Seltsi aastaraamat 35-42 (1989-1996). Tartu, 191-195.

Meri, Mart 1998b. Emakeele Seltsi 71. tegevusaasta (1990). - Emakeele Seltsi aastaraamat 35-42 (1989-1996). Tartu, 203-208.

Meri, Mart 1998c. Emakeele Seltsi 75. tegevusaasta (1994). - Emakeele Seltsi aastaraamat 35-42 (1989-1996). Tartu, 245-251.

Päll, Peeter 1985. Nn. käändumatu omadussõna õigekirjast. („,Kirjakeele korraldus nüüd ja praegu“.) - Keel ja Kirjandus 5, 274-281.

Päll, Peeter 2010. Mida on uut keeletoimkonnas. - Oma Keel 1, 40-43.

Päll, Peeter 2018. Miks maanimed muutuvad. - Oma Keel 2, 54-58. 
Päll, Peeter 2019. Pilk eesti kirjakeele korraldamise sajandile ja tänapäevale. Keel ja Kirjandus 1-2, 107-111.

Raadik, Maire 2017. Uudissõnu uue aastatuhande algusest. Tallinn: Tänapäev.

Raadik, Maire 2019. Emakeele Seltsi keeletoimkonna veerandsajand. - Oma Keel 1, 54-67.

Saari, Henn 2004. Keelehääling. Eesti Raadio „Keeleminutid“ 1975-1999. Tallinn: Eesti Keele Sihtasutus.

Valge, Jüri 2020. Sajand koos Eestiga. Emakeele Selts 1920-2020. Tallinn. 


\section{The language committee of the Mother Tongue Society in the second half of the 20th century}

\section{TIIU ERELT}

The first half of the article is an overview of the fruitful first period of activity of the language committee of the Mother Tongue Society, from 1969-1972. Afterwards, other language committees began operating and the Society's language committee remained largely unnecessary until the 1990s. In 1993 the committee was recreated, thus beginning the second period of its activity (continuing up to the present day), which is described briefly in the article, referring to previously published overviews. Instead of repeating these, the article focuses on the discussions of initial letter orthography through the years, beginning with the correction of the orthography of so-called indeclinable adjectives and ending with a clearer set of rules, as published in the 1994 "On initial letter orthography and quotation marks" and its subsequent supplements. The activity of the committee has always been founded on the results of the study of Estonian and on language planning theory.

Keywords: Mother Tongue Society, language committee, Estonian language planning, recommended language use, language rules

Tiiu Erelt

Emakeele Selts

Roosikrantsi 6

10119 Tallinn

mati.erelt@ut.ee 